\title{
KESESUAIAN ANTARA KONSEP DIRI NYATA DAN IDEAL DENGAN KEMAMPUAN MANAJEMEN DIRI PADA MAHASISWA PELAKU ORGANISASI
}

\author{
Juriana \\ Universitas Gadjah Mada
}

\section{INTISARI}

Penelitian ini bertujuan untuk mengetahui hubungan antara kesesuaian konsep diri nyata dan ideal dengan kemampuan manajemen diri pada mahasiswa pelaku organisasi. Selain itu, juga akan dilihat apakah ada perbedaan kemampuan manajemen diri antara pelaku organisasi yang berstatus top executive (ketua umum) dengan yang berstatusnon top executive (ketua bidang).

Subjek penelitian berjumlah 72 orang. 36 orang berstatus ketua umum dan 36 orang ketua bidang pada organisasi kemahasiswaan, semuanya berusia 18-24 tahun. Analisis data yang digunakan adalah uji korelasi dengan product-momentdari Pearson dan uj perbedaan dengananava 1 jalur.

Hasil analisis menunjukkan adanya hubungan yang sangat signitikan antara kesesuaian konsep diri nyata dan ideal dengan kemampuan manajemen diri pada mahasiswa pelaku organisasi $(r x y=-0.801 ; p<$ $0,01)$. Sumbangan kesesuaian konsep diri nyata dan ideal ternadap kemampuan manajemen diri sebesar $63,1 \%$. Hasil analisis tambahan menunjukkan tidak adanya pebedaan kemampuan manajemen diri antara pelaku organisasi yang berstatus top excutive dengan yang berstatus non top executive $(F=0,003 ; p>0,05)$.

Kata kunci: konsep diri, manajemen diri, pelaku organisasi

Juriana, adalah alumni Fakultas Psikologi UGM. Saat in sedang menempuh pendidikan prolesi di Fakultas Psikologi Universitas indonesia Jakarta.
Q eiring dengan era reformasi yang ter$\checkmark$ jadi di Indonesia, mahasiswa muncul sebagai "pahlawan retormasi". Hal ini dise. babkan masyarakat menganggap mahasiswa sebagai pelopor gerakan pembaharuan bangsa tersebut. Bentuk kepedulian yang lazim dipilih mahasiswa untuk mewujudkan kepedutiannya terhadap nasib bangsa adalah unijuk rasa. Menurut Laporan Tim KA (1998), kebanyakan tokoh aksi unjuk rasa itu merupakan pengurus organisasi kemahasiswaan yang ada d kampusnya (Wicaksana 1998). Sebagai anggota organisasi maha- 
siswa, mereka tidak sekedar terliba: kegiatan demonstrasi yang bersifa: insidentil, namun juga mengorganisasikan demonstrasi dan unjuk rasa tersebut yang membutuhkan waktu dan energi. Hal ini menyebabkan mereka harus menambah sugas baru di samping belajar dari perkuliahan (Utami, 1998). Peneliti melihat bahwa kondisi seperti inilah yang membedakan mereka dari mahasiswa yang hanya berorientasi pada studi. Tuntutan untuk lebih mampu melakukan manajemen diri pada mahasiswa pelaku organisasi nampaknya menjadi lebih besar. Kemampuan melakukan manajemen diri ini semata-mata ditujukan agar tercapai keseimbangan antara kehidupan organisasi dan akademis yang mereka jalani. Dengan kata lain, hal ini ditujukan agar mahasiswa pelaku organisasi dapa: menimba pengakman di organisasi namun mereka juga tidak :erlena hingga mengabaikan tugas akademisnya.

Sejauh ini, nampaknya hanya sedikit ahli melakukan pembahasan mengenai manajemen diri. Manajemen diri, oleh Gie (1996), diartikan sebagai segenap kegiatan dan langkah mengatur dan mengelola diri dengan sebaik-baiknya sehingga mampu membawa ke arah tercapainya tujuan hidup. Covey (1994) mengaitkan manajemen diri dengan manajemen waktu, Covey (1994) mendefinisikan manajemen diri sebagai cara individu mengorganisasi kehidupannya dengan prinsip mendahulukan apa-apa yang harus didahulukan. Pengertian yang dikemukakan Covey (1994) disebabkan karena waktu merupakan aset yang sangat berharga.

Douglas dan Douglas (1980) menyatakan bahwa kehidupan setiap individu idak dapa: dilepaskan oleh waktu. Setiap individu akan melakukan pengaturan waktu sejalan dengan kebutuhannya untuk menga:ur pekerjaannya. Karena itu, seseorang yang mampu mengelola keduanya dengan benar. dapat dikaiakan la mampu mengelola dirinya dengan baik. Sementara Lakein (1997) dalam bukunya "How To Get Control of Your Time and Your Life" menyebutkan bahwa : "Waktu adalah hidup. la sidak dapa: diulang dan diganti. Bila Anda memboroskan waktu, berarti Anda memboroskan hidup, tetapi bila Anda menguasai waktu, berarti Anda mengua sai hidup dan mengambil manfaat yang sé baik-baiknya dari hidup."

Peneitian Macan, dkk (1990) menemukan bahwa siswa yang memiliki kontrol waktu merasakan tekanan sekolah dan tekanan somatis yang lebih rendah daripada siswa yang tidak memiliki kontrol terhadap waktu yang dimilikinya. Penelitian Macan (1994) selanjutnya menunjukkan bahwa persepsi ientang pengontrolan waktu berhasil menurunkan tekanan kerja, menurunkan tekanan somatik, dan meningkatkan kepuasan kerja.

Kontrol memang merupakan kunci manajemen waktu. Kegagalan mengontrol waktu inilah yang kemudian memunculkan tiga macam karakter manusia sebagaimana dikemukakan Lakein (1997). Pertama, manusia yang "gila" pengorganisasian. Manusia dengan tipe seperti ini akan senantiasa menyusun dan memperbaharui daftar pekerjaan yang akan dilakukannya. la belum bergerak sebelum membua: rencana sedetildetilnya. la lebih tertarik membayangkan dirinya terorganisir dibandingkan melakukan sesuatu. Hal ini sering membuatnya tidak mampu meliha: perubahan, kesempatan baru dan kebutuhan orang lain.

Kedua, manusia yang overdoer. Manusia dengan tipe seperti ini akan selalu sibuk melakukan berbagai hal sehingga tidak mempunyai waktu lagi untuk melihat nilai sebenarnya dari pekerjaannya itu. la luar biasa efisten, narrun sekaligus kehilangan spontanitas dan fleksibilitasnya. Detik demi detik selalu diisi dengan pekerjaan yang membua: ia tidak pernah mempunyai waktu untuk beristirahat. 
Ketiga, Marusia yang "gila" waktu. Manusia dengan tipe seperti ini akan selalu membuat dirinya darn orang-orang di sekitarnya menjadi gelisah karena usahanya yang seriantiasa memenuhi batas waktu yang mustahil. ka menjadi tipe orang yang tidak menyenangkan urituk dijadikan teman bergaul atau temar beker ja.

Menurut Lakein (1973), deskripsi atas manajemer waktu pertama kali dimulai derigarı menentukan apa yang sebenarnya menjadi kebutuharı dan keinginan individu, kemudian merigurutkan kebuzuhan dan keinginan lu berdasarkan tingkat kepentingannya. Aktivitas yang spesifik meliputi tujuan dari kebutuhar atau keinginan tersebut, dan kemudiar membuat prioritas dalam pencapaiarriya. Aktivitas-aktivitas yang paling penting dihubungkan dengan waktu dan sumber daya yang ada melahui perencanaan. perjadwalan, dan pembuatan daitar. Lakein juga menggambarkan beberapa kat manajemen waktu lainnya, seperti mengorganisasikan lingkungan kerja dan menentukan pendekatan terhadap proyek yang bersangkutar.

Berdasarkan deskripsi Lakein (1973) tersebut, Macan, Shanarii, Dipoye dan Phisips (1990) menemukan tiga faktor yang ada dalam manajemen waktu yang dipakai dalam pengembarigan pengukuran atas manajemen waktu, yaitu penentuan tujuan dan prioritas, teknik manajemen waktu, dan kecenderungan untuk terorganisasi.

Portama, penentuar tujuan dan prioritas, yaitu apa yang menjadi keinginan dan kebutuharı seseorang untuk diselesaikan, dan bagaimana ia menempatkan prioritas tugas yang diperlukan guna mencapai tujuannya tersebut. Menurut Covey (1994). tujuar yang ditentukan ofeh seorang individu merlyangkut keselarasan dan integrasi visi dan misi yang dimiliki. Melalui pendekatan tujuan, Covey (1996) menambahkan bahwa dengar menentukan tujuan individu akan mencapai sesuatu yang lebih banyak dar pada kenyataannya orarig yang tahu bagaimana merierapkan dan merain tujuan umum nya dapat menyelesaikan apa yang mereka lakukan. Pendekatan tersebut mencakup tujuan jangka pendek, jangka menengah, jangka panjang, penetapan tujuan, visualisasi, motivasi diri, dan penciptaan sikap mental positif. Menurut Manz (1992), perilaku individu akan dipengaruhi secara positif oleh sasaran, tujuan, cita-cita pribadi yang ditentukan secara sistematis, yang dipikir dalam-dalam, dituiju dengan sekuat tenaga serta sekuat hati.

Sebagaimanan dikatakan Covey (1996), setiap orarig dapat melakukan sesuatu yang ia inginkan. tetapi tidak segala sesuatu. Karena itu diperlukan urutam-urutar tujuan dengan beberapa cara seperti klarifikasi nila dan perjenjangan tugas. Menurut Lakein (1997), penentuan prioritas berkaitan dengan tingkat kepentingan. Pendekatan $\mathrm{ABC}$ yang dikenalkan Lakein (1997) membantu individu untuk mendahulukan aktivitas yang berprioritas tinggi ataupun membuang aktivitas yang berprioritas rendah.

Kedua, tekrik manajemen waktu, yaitu cara-cara yang digunakan dalam mengeloia waktu, seperti membuat daftar, jadwal, darı rencarla kerja. Berkaitan dengarı cara-cara pengelolaan waktu tersebut, Covey (1994) mewajibkarı adariya ala: bantu yang bersifat portabilitas, mudah dibawa kemana-mana sehirigga akan selalu berada bersama pemiliknya, yang oleh Manz (1992) disebut agenda. Daftar yang berada di dalam agenda disusun berdasarkan prioritas sedemikian rupa sehingga tidak sekedar berguna sebagai peringatarı darı membantu dalam peiaksanaan, tetapi juga dapat merupakan dasar untuk memiliki rasa "untuk menyelesajkan" sesuatu.

Ketiga, kecenderungan urtuk terorganisasi, yaitu kecenderungan kerja seseorang dihuburigkan dengan cara bagaimana ia 
mengatur lingkungan kerja di sekitarnya. Menurut Covey (1996), pendekatan keteraturan dapat menghemat waktu dan menyebabkan efisiensi yang yang besar. Individu tidak memboroskan waktu untuk mencari barang-barang yang yang tercecer. Menurut Manz (1992), untuk membantu individu bertindak secara baik la dapat menjauhkan benda, barang, hai yang mengganggu dan sebaliknya, memantatkan benda, barang, hal yang mendukung pelaksanaan tugasnya. Pengaturan menyebabkan kejelasan pikiran dan keteraturan. Pengaturan yang dikemukakan Covey (1992) mecakup pengorganisasian dalam tiga bidang. yaitu pengorganisasian bendabenda, pengorganisasian tugas-tugas, dan pengorganisasian orang.

Ketiga faktor manajemen waktu ini kemudian dijadikan pedoman oleh Macan. dkk (1990) untuk menyusun skala manajemen waktu, yang kemudian dikenal dengan nama Time Management Behavioral Scale (TMB Scale).

Berdasarkan uraian tentang faktor-faktor manajemen waktu, dapat disimpulkan bahwa yang dimaksud dengan manajemen waktu bukanlah kegiatan yang semata-mata mengatur, membagi, dan menjadwal waktu yang dimiliki untuk aktivitas-aktivitas yang dijalani. Manajemen waktu juga mencakup pemberian makna terhadap aktivitas-aktivitas tersebut. Pemberian makna ini kemudian mewujudkan penetapan tujuan untuk setiap kegiatan tadi. Penetapan tujuan ini selanjutnya akan menstimulasi individu untuk melakukan tindakan-tindakan efektil berikutnya. Tindakan-tindakan yang dimaksud setidaknya terbagi menjadi dua. Pertama, dengan cara menetapkan skala prioritas bagi kegiatan-kegiatan yang dijalani Kedua, dengan cara mengatur atau mengorganisasikan điri dan lingkungan yang dapat memperlancar pelaksanaan kegiatan-kegiatan tersebut.
Lebih jauh Gie (1996) menjelaskan tentang strategi manajemen diri. Menurutnya, strategi pertama dan utama dalam manajemen diri adalah berusaha mengetahui dri sendir dengan segala kelebihan dan kekuatannya maupun kekurangan dan potensinya. Selanjutnya seseorang menerima dirinya sebagaimana adanya tanpa senantlasa berkeluh kesah. Hal-hal yang tidak dapat diubah hendaknya diterima dengan kedamaian, sedang hal-hal yang dapat diperbaiki hendaknya diusahakan penyempurnaannya.

Strategi manajemen diri yang telah dikemukakan oleh Gie (1996) tersebut sejalan dengan salah satu faktor yang mempengaruhi manajemen diri, yaitu pengembangan identitas diri. Menurut Pedier dan Boydell (1985), sejauh mana seorang individu mampu mempertahankan (surviving), memelihara (maintaining), dan mengembangkan (developing) aspek identitas diri yang dimilikinya (selain aspek kesehatan, ketrampitan atau keahlian, dan aktivitas hidup) akan menentukan tingkat kemampuan manajemen diri yang dapat ia lakukan.

Mengenal identitas din itu sendiri, menurut Prawitasari (1993) tidak hanya terbatas pada nama, umur, jenis kelamin. pendidikan, pekerjaan atau status perkawinan, tetapi juga mengenal konsep dirinya. Melalui konsep diri, individu dapa: memperoleh gambaran tentang dirinya secara utuh. Brooks (dalam Rakhmat, 1985), mendelinisikan konsep diri sebagai persepsi mengenai diri individu sendiri baik yang bersifat fisik, sosial, dan psikologis yang diperolah melalui pengalaman dan interaksi individu dengan orang lain. Sementara Rakhmat (1985) mengatakan bahwa konsep diri bukan hanya sekedar gambaran deskriptif saja, melainkan juga penilaian orang tersebut terhadap dirinya. Jadi konsep diri meliputi apa yang dipikirkan 
dan apa yang dirasakan tentang diri individu sendiri. Dengan demikian ada dua komponen konsep diri yaitu komponen kognitif dan komponen afektif. Komponen kognitif disebut dengan citra diri (se/l image) dan komponen afektif disebut sebagai harga diri (self esteem).

Menurut Rogers (1961), diri atau konsep diri adalah bentuk konseptual yang tetap, leratur, dan koheren yang dibentuk oleh persepsi-persepsi lentang kekhasan dari "aku" dan persepsi-persepsi tentang hubungan antara "aku" dengan yang lain, dengan beberapa aspek hidup bersama dengan nilai-nilai yang dimiliki persepsipersepsi ini. Rogers (dalam Calhoun \& Acocella, 1995) juga memandang konsep diri sebagai gambaran mental diri sendiri yang terdiri dart pengetahuan tentang diri, pengharapan bagi diri dan penilaiar terhadap diri sendiri. Pengertian ini menunjukkan bahwa konsep diri memiliki tiga dimensi, yaitu pengetahuan, harapan, dan penilaian. Dimensi pengetahuan, yaitu segala pengetahuan atau informasi yang individu ketahui tentang dirinya, seperti umur, jenis kelamin, penampilan, dan sebagainya. Dimensi harapan, yaitu suatu pandangan tentang kemungkinan menjadi apa individu di masa mendatang, atau dengan kata lain dimensi harapan ini merupakan gambaran tentang diri ideal, Dimensi penilaian, yaitu penilaian individu tentang gambaran siapa dia dan gambaran tentang seharusnya menjadi atau menjadi apa dia. Bila kenyataan diri individu (apa yang memang berar tentang dirinya) dan diri ideal individu (apa yang ia rasakan sebagai seharusnya) bebeda sekali, sangat mungkin individu tersebut akan merasa tidak bahagia dengan dirinya sendiri. Semakin besar perbedaan tersebut, semakin besar pula ketidakpuasan itu.

Berdasarkan dimensi tersebut, Rogers (1961) membedakan dua macam konsep diri, yaitu konsep diri yang real dan ideal.
Konsep diri yang real, yaitu pandangan tentang diri yang sebenamya yang kemudian disebut sebagai "diri yang organismik" yang merupakan dasar realitas psikis dan memiliki "prioritas mutlak". Konsep diri yang ideai, yaitu suatu pandangan tentang diri sendiri sebagaimana didam-idamkan atau seperti yang seharusnya.

Sejalan dengan Rogers (1961), Burns (1979) menyatakan bahwa kebanyakan orang jika diminta untuk menggambarkan diri mereka sendiri, maka mereka membua: perbedaan antara "siapa diri mereka" dan "ingin menjadi apa mereka". Pernyataan ini sesuai dengan pernyataan Middlebrook (1974) yang menyatakan bahwa setiap individu selalu memperbandingkan diri nyata terhadap diri idealrya dan pernyataan tersebut juga menghasilkan pengertian bahwa diri ideal selalu relatif berbeda dari diri nyata.

Lebih lanjut Rogers (1961) mengatakan bahwa setiap individu seharusnya tidak sekedar mempunyai gambaran tentang diri nyata dan diri idealnya, namun juga mempunyai kesesuaian di antara keduanya. Penyesuaian antara diri nyata dan diri ideal itulah yang akan menciptakan kondisi kongruen pada individu. Dalam keadaan kongruen, individu benar-benar membuka diri atas semua pengalaman yang dialaminya, baik yang terjadi di dalam maupun di luar dirinya. Keterukaan terhadap pengalaman membuat individu mampu memandang diri dan duria luar sebagai realitas yang objektif. sehingga mampu memanfaatkan seluruh potensinya sekaligus potensi di luar dirinya secara maksimal. Dalam kondisi seperti ini. individu lebih mampu mengarankan dan mengorganisasikan kehidupannya dengan sebaik-baiknya. Dengan kata lain. penyesuaian antara konsep diri nyata dan ideal akan membantu individu melakukan manajemen terhadap dirinya.

Berkaitan dengan kesesuaian antara konsep diri nyata dan ideal ini, Rogers

PSIKOLOGIKA NommI 9 Tahun V 2000 
(dalam Stephenson, 1968) menciptakanQsort sebagai alat ukur konsep diri bagi klien yang akan melakukan psikoterapi. Klien diukur konsep dirinya yang terdiri dari diri nyata dan diri ideal melalui permainan menempatkan kartu-kartu yang berisi pernyataan-pernyataan (sorting cards) sebelum dan setelah proses terapi. Penempatan kartu-kartu berupa forced choice agar membentuk distribusi normal, atau terbagibagi menjadi kuartil-kuartil, sehingga alat ukur ini dinamakan Q-Sort. Melalui skor pretest dan post-test tersebut akan dapat dilihat seberapa besar kemajuan yang dialami klien selama proses terapi. Rogers berpendapat bahwa konsep diti seseorang memiliki pengaruh yang kuat dalam permasalahan yang dialaminya. Menurutnya, individu yang terganggu disebabkan oleh keadaan dirinya yang inkongruen, sebuah situasi di mana terdapat ketidaksesuaian antara konsep diri nyata dan ideal yang inggi. Karena itu, perbandingan keadaan konsep diri sebelum dan sesudah terapi menjadi suatu hal yang penting untuk diketahui, apakah klien mengalami kemajuan dalam kesesuaian konsep dirinya setelah diterapi atau tidak.

Metode ini dianggap sebagai suatu penemuan baru yang mencakup pengukuran psikotenomenologis sekaligus statistik. Kelebihan lainnya bahwa bentuk pengukuran yang dilakukan menyerupai permainan. yang membuat klien tidak begitu merasa dirinya diukur sebagaimana angket biasanya (Stephenson, 1968).

Metode ini digunakan oleh para peneliti antara lain karena dapat mereduksi keraguan individu dalam memperoleh gambaran tentang dirinya. Keraguan itu dapat teratasi manakala individu yang bersangkutan diberi dua kesempatan sekaligus dalam menggambarkan dirinya, yaitu: bagaimana la berperilaku di masa yang lampau dan bagaimana kemungkinan ia berperilaku di masa yang akan datang. Selain itu, karena metode ini dioperasikan oleh individu sendiri, maka dianggap mampu menyediakan data yang akurat (Stephenson, 1968).

Q-Sort inilah yang kemudian dikembangkan oleh Butler dan Haigh (dalam Rogers \& Dymond, 1956). Menurut Robinson dan Shaver (1974), butir-butir hasil studi studi Butler dan Haigh (dalam Rogers \& Dymond, 1956) ini banyak yang bermanfaat dan dapat digunakan para peneliti meskipun dalam format yang lain. Butir-butir yang ada merupakan variasi dari berbagai ruang konsep diri, seperti: penerimaan diri, keadaan fisik, kecemasan, tuntutan pada diri, dan keselmbangan. Buter dan Haigh (dalam Rogers dan Dymond, 1956) kemudian membagi pernyataan-pernyataan tersebut menjadi pernyataan-pernyataan yang bemilai positif ( + ) dengan dasar pola konsep diri positif dan pemyataan-pernyataan yang bemilai negatif ( $\gamma$ ) dengan dasar pola konsep diri negatif.

Beberapa ciri yang dimiliki orang-orang dengan pola konsep diri positit seperti: mempunyai penerimaan din positit terhadap dirinya sendiri, pengetahuan yang luas dan bermacam-macam tentang diri, penghargaan yang realistis, harga diri yang tinggi, memiliki pola perilaku optimis, tidak mudah menyerah, dan selalu ingin mencoba pengalaman baru yang dianggapnya ber. guna (Rogers dalam Hall dan Lindzey, 1959; Grinder, 1978; Surakhmed, 1980, Cahoun \& Acocella, 1995). Sementara ciri-ciri orang dengan pola konsep diri negatif seperti: berperilaku negatit, pengetahuan yang tidak tepat tentang diri sendiri, pengharapan yang tidak realistis, harga diri yang rendah, menganggap dirinya kurang mampu, takut menghadapi hal-hal baru, dan takut tidak berhasil. (Rogers dalam Hall dan Lindzey. 1959; Grinder, 1978; Surakhmad, 1980. Calhoun \& Acocella, 1995). 


\section{Hipotesis}

Dari penjelasan di atas dapat dirumuskan hipotesis sebaagi berikut. Ada hubungan yang positif antara kesesuaian konsep diri nyata dan ideal dengan kemampuan manajemen diri.

Semakin tinggi kesesuaian antara konsep diri nyata dan ideal yang dimiliki mahasiswa pelaku organisasi, semakin tinggi pula kemampuan manajemen diri yang dapat dilakukannya.

\section{METODE PENELITIAN}

\section{Variabel-variabei Penelltian}

Dalam penelitian ini, sebagai variabel prediktor adalah kesesuaian konsep diri nyate dan ideal. Variabel kriteriumnya adalah kemampuen manajemen diri.

\section{Subjek Penelilian}

Subjek penelitian adalah pengurus organisasi kemahasiswaan tingkat fakultas di lingkungan UGM, terdiri dari ketua umum (36 orang) dan ketua bidang (36 orang) dari Senat Mahasiswa Fakultas (SMF) dan Badan Eksekutif Mahasiswa Fakultas (BEMF) di 18 fakultas yang ada di UGM, sehingga jumlah keseluruhan subjek 72 orang. Subjek berusia 18-24 tahun.

\section{Alat Pengumpul Data}

Pengumpulan đata penelitian ini dilakukan dengan menggunakan Q-Sort kesesuaian konsep diri nyata dan ideal serta angket kemampuan manajemen diri.

1. Q-Sont Kesesuaian Konsep Diri Nyata dan Ideal

Sistem Q-Sort yang digunakan dalam penelitian ini adalah hasil proses adaptasi yang terdiri dari 50 butir hasii studi Butler dan Haigh (Rogers dan Dymond, 1956).
Setelah dilakukan uji coba, didapatkan aitem-aitem yang sahih, yaitu untuk diri nyata berisi 21 pernyataan positif dan 8 pernyataan negatif, begitu pula dengan din ideal, sehingga secara total beriumlah 58 butir. Perbedaan administrasi yang dipakai di sini bahwa subjek tidak diberi instruksi yang bersifat forceo choice. Hal ini dilakukan mempertimbangkan efisiensi penelitian.

Masing-mesing butir diberikan kepada subjek dalam bentuk kartu. Subjek diminta menempatkan kartu-kartu tersebul satu per satu ke dalam sembilan kotak di bawah dua kondisi. Pertama, bagaimana subjek menggambarkan dirinya sebagaimana adanya (actual-sel/h dan kedua, bagaimana subjek menggambarkan dirinya sebagaimana yang didambakannya (ideal-selin. Penempatan kartu di dalam kotak mengikuti rentang 19 dengen keterangan bahwa semakin ke kiri (menuju angka terendah atau angka 1) berarti semakin tidak sesuai, dan semakin ke kanan (menuju angka tertinggl atau angka 9) berarti semakin sesuai. Pemberian skor adajah sebagai berikut:

- Untuk pemyataan-pemyataan positif penilaian bergerak dari satu sampai sembilan

- Untuk pemyalaan-pemyataan negatif penitaian bergerak dari sembilan sampai satu

Untuk menentukan tara kesesuaian konsep diri nyata dan ideal yang dimiliki subjek dapal dilihat dan selisih jumlah kedua pengukuran. Semakin rendah jumlah skor yang diperoleh berarti semakin tinggi tara kesesuajan konsep diri nyata dan idealnya. begitu pun sebaliknya. Semakin tinggi jumlah skor yang diperoleh, berarti semakin rendah tara kesesuaian konsep diri nyata dan idealnya (Wijayanti, 1992).

\section{Angket Kemampuan Manajemen Diri}

Angket kemampuan manajemen diri mengacu pada Time Management Behav- 
ioral Scale (TMB Scale) yang disusun oleh Macan (1990) berdasarkan faktor-faktor yang digolongkan dalam manajemen waktu, yaitu: (a) penentuan tujuan dan prionitas, (b) teknik manajemen waktu. (c) kecenderungan untuk terorganisasi.

Setelah dilakukan uji coba, disusunlah angket kemampuan manajemen diri ini yang terdiri dari 58 butir, 31 butiffavorable dan 27 butir unfavorable. Masing-masing butir mempunyai empat alternatif jawaban, yaitu: SS (sangat sesuai), S (sesuai), KS (kurang sesuai), dan TS (tidak sesuai). Penifaian bergerak dari empat sampai satu untuk butir-butir yang favorable, dan satu sampai dengan empat untuk butir-butir yang unlavorable.

Untuk menentukan taraf kemampuan diri yang dimiliki subjek dapat dilihat dari jumlah skor angket tersebut. Semakin tinggi jumlah skor yang dperoleh, berarti semakin tinggi kemampuan manajemen dirinya. begitupun sebaliknya.

\section{Wawancara.}

Peneliti melengkapi penelitian dengan pedoman wawancara yang besifat umum. Pedoman wawancara mencantumkan isuisu yang ingin diliput, yaitu: (a) keaktifan berorganisasi (riwayat organisasi dan pertimbangan aktif dalam organisasi kemahasiswaan); (b) masalah-masalah selama berorganisasi; (c) manajemen diri; (d) pengenalan diri; (e) peran pengenalan diri bagi manajemen diri; (f) gambaran tentang masa depan; dan (g) kontribusi pengalaman berorganisasi.

Untuk subjek yang berstatus ketua bidang hanya diberikan angket kemampuan manajemen diri.

\section{Analisis Data}

Pengujian hipotesis penelitian ini menggunakan teknik korelasi proofuct-moment dari Pearson. Untuk analisis tambahan menggunakan uji perbedaan anava 1 jalur. Semua analisis data ini menggunakan paket Statistical Product and Service Solution (SPSS) Versi 7.5 for Windows.

\section{HASIL PENELITIAN}

Penelitian dilakukan secara satu persatu terhadap mahasiswa pelaku organisasi. Hal ink berkaitan dengan pelaksanaan 0 -Sort yang membutuhkan tatap muka secara langsung antara peneliti dan subjek penelitian. Pelaksanaan penelitian berlangsung selama bulan Juni hingga Juli 1999.

Hașil ui linieritas menunjukkan hubungan yang linier antara variabel kesesuaian konsep diri nyata dan ideal dengan kemampuan manajemen diri $\{F=77,926$ dan $p<0,001$ ). Selanjutnya uji korelasi product-moment menunjukkan bahwa ada hubungan negatif yang sangat signifikan antara skor selisih diri nyata dan ideal dengan skor kemampuan manajemen diri ( $\mathrm{rxy}=-0,801$ dan $\mathrm{p}<$ $0,01)$. Dengan demikian, hipotesis yang diajukan dalam penelitian ini, yaitu semakin tinggi kesesuaian antara konsep dir nyata dan ideal yang dimiliki mahasiswa pelaku organisasi, semakin tinggi pula kemampuarı manajemen diri yang dapat dilakukannya, diterima. Sumbangan efektif kesesuaian konsep diri nyata dan ideal terhadap kemampuan manajemen diri adalah sebesar $63.1 \%$ (koefisien determinasi sebesar 0,631).

Selain itu, hasil analisis tambahan dengan uji perbedaan anava 1 jalur menunjukkan fidak adanya perbedaan yang signifikan antara kemampuan manajemen díri mahasiswa pelaku organisasi yang berstatus top executive dengan yang berstatus non top executive ( $F=0,003$ dan $p>0,05$ ).

Berdasarkan kategorisasi skala kesesuaian konsep diri nyata dan ideal dengan kurve normal dikelahui bahwa subjek secara 
umum mempunyai tingkat kesesuaian konsep diri nyata dan idoal yang sangat tinggi $(M=47,17 ; S D=22,01)$. Sementara skor kemampuan manajemen diri subjek berdasarkan kategorisasi secara kurve normal secara umum adalah sangat tinggi $(M$ $=178,11 ; \mathrm{SD}=17,84)$.

\section{PEMBAHASAN}

Berdasarkan hasil analisis data, $d$ ketahui bahwa terdapat hubungan yang sangat signifikan antara kesesuaian konsep diri nyata dan ideal dengan kemampuan manajemen diri pada subjek penelitian. Semakin tinggi kesesuaian antara konsep diri nyata dan konsep diri ideal subjek, semakin tinggi pula kemampuan manajemen diri yang dimilikinya. Begitupun sebaliknya, semakin rendah kesesuaian antara konsep diri nyala dan konsep diri ideal subjek, semakin rendah pula kemampuan manajemen diri yang dimilikinya.

Hubungan antara kesesuaian konsep diri nyata dan ideal dengan kemampuan manajemen diri pada subjek penelitian dapat dijelaskan sebagai berikut: Pertama, individu yang mampu melakukan penyesuaian antara konsep diri nyata dan idealnya, berarti ia mampu mengintegrasikan antara keadaan diri yang sebenarnya dengan keadaan diri yang diharapkannya. Jika ia memiliki konsep diri ideal, maka yang akan dilakukannya adalah membentuk konsep diri ideal yang realistik (Partosuwido, 1992). Dalam kondisi seperti itu, individu akan menentukan atau memilih tujuan-tujuan tertentu yang memungkinkan untuk dicapai (Hurlock, 1974; Kanfer, 1975). Namun begitu, pemilinan tujuan-tujuan tersebut tetap memperhatikan pada apa-apa yang memberi makna pada dirinya, membuat dirinya semakin berarti, dan sesuai dengan visi dan misi hidup yang dimilikinya (Macan, 1990; Covey, 1994: Lakein, 1997).
Kedua, penyesuaian antara konsep diri nyata dan ideal yang dilakukan seorang individu, akan mempermudah individu tersebut melakukan penyesuaian diri dalam pelaksanaan aktivitasnya. Hal ini disebabkan individu memahami keterbatasan yang dimilikinya, bahwa ia tidak dapat melakukan segala hal yang diinginkannya. Atas dasar itulah, individu kemudian melakukan tindakan-tindakan efektif tertentu dalam hidupnya, seperti pembuatan skala prioritas aktivitas dan mengorganisasikan diri serta lingkungan yang mendukung pelaksanaaan aktivitas-aktivitas tersebut (Macan, 1990; Covey, 1994; Lakein, 1997).

Ketiga tingkat kesesuaian antara konsep diri nyata dan ideal yang tinggi, menunjukkan bahwa individu memiliki keterbukaan yang was terhadap pengalaman hidupnya, baik yang berasal dari dalam maupun dari luar dirinya. Kelerbukaan terhadap pengaiaman akan membawa individu menyadari segala potensi diri yang dimilikinya, baik yang berupa kekuatan maupun kelemahan. Kondisi seperti in dapat memudahkan individu dalam mengarahkan kehidupannya dan merencanakan masa depannya (Rogers, 1961; Saam. 1988)

Berdasarkan hasil wawancara, diperoleh informasi bahwa subjek penelitian mendapatkan gambaran tentang konsep dirinya melalui dua sumber, yaitu dari diri sendiri dan dari orang lain. Gambaran dari diri sendini diperoleh dengan cara melakukan proses kesadaran diri (awareness), yang biasanya dikenal dengan istilah introspeksi. Sementara gambaran dari orang lain diperoleh dengan cara meminta umpan balik atau masukan dari orang lain. Berdasarkan kedua hal tersebut, subjek bisa mengetahui kekuatan dan kelemahan yang dimilikinya. Dengan mengetahui kekurangan dan kelebihan tersebut, subjek merasa lebih mampu melakukan penyesuaian diri. Penyesuaian diri yang dilakukan tidak lain bertujuan untuk 
mengarahkan kehidupan dengan sebaikbaiknya. Dengan kata lain, secara tidak langsung, hat ini menguatkan hipotesis yang diajukan peneliti tentang adanya hubungan antara kesesuajan konsep diri nyata dan ideal dengan kemampuan manajemen diri.

Berdasarkan hasil analisis data, diketahui juga bahwa kesesuaian antara konsep diri nyata dan ideal memberi sum. bangan yang cukup besar yaitu 63.10 persen terhadap kemampuan manajemen diri. Besarnya sumbangan tersebut disebabkan konsep diri itu sendiri memiliki posisi yang penting dalam menentukan tingkah laku individu. Individu akan bereaksi pada situasi sesuai dengan persepsi tentang dirinya dan dunianya. la bereaksi pada realitas seperti yang dipersepsikan olehnya dengan cara yang sesuai dengan konsep dirinya (Rogers dalam Rakhmat, 1985). Sementara Markus dan Wurt (dalam Partosuwido, 1992) menguatkan bahwa konsep diri adalah komponen yang dinamis dari sistem kognitif dan afektil dalam diri individu yang berfungsi untuk mengarahkan dan mengendalikan perilaku. Lebih jauh, pentingnya peranan konsep diri dikarenakan konsep diri merupakan internal frame of reforence, yaitu acuan tingkah laku dan penyesuaian seseorang (Meichati dalam Sulistyani, 1990).

Hasil penelitian ini juga menunjukkan tidak adanya perbedaan tingkat kemampuan manajemen din antara mahasiswa pelaku organisasi yang berstatus top executive (ketua umum) dengan yang berstatus non top executive (ketua bidang). Hal ini nampaknya terjadi berkaitan dengan kondisi organisasi kemahaiswaan itu sendiri. Sebagaimana diketahui bahwa organisasi Kemahasiswaan adalah wahana dan sarana pengembangan diri dan aspirasi mahasiswa ke arah perluasan wawasan dan kecendekiawanan serta integritas kepribadian. Dengan demikian, organisasi kemahasiswaan adalah tempat berlath bagi para maha- siswa, bukan organisasi yang menuntut cara kerja yang profesional. Karena itu, tidaklah mengherankan jika kebanyakan subjek penelitian mengatakan bahwa organisasi kemahasiswaan lebih bersilat profesional moral, bukan protesional kerja. Hal ini menyebabkan tinggi rendah kemampuan manajemen diri yang ada di kalangan mahasiswa pelaku organisasi tidak dapat ditentukan dari jabatan yang dimiliki, melainkan bersitat reiatif, tergantung kepada kesadaran masing-masing individu. Dengan kata lain, d dalam organisasi kemahasiswaan tidak ada tuntutan secara formal bagi pemegang jabatan tertentu untuk melakukan manajemen diri dengan tingkat tertentu pula, sehingga jabatan tidak dapat dijadikan prediksi atau bahan acuan untuk menentukan perbedaan lingkat kemampuan manajemen diri.

Berdasarkan semua uraian yang ada, dapat disimpulkan bahwa konsep diri menempati posisi yang penting dalam me nentukan perilaku individu. Perilaku individu akan terarah dengan baik lika la dapat melakukan penyesuaian antara konsep din nyata dan konsep diri ideal yang dimilikinya. Kesesuaian antara konsep diri nyata dan ideal akan menciptakan kondisi kongruen pada individu, yaitu suatu kondisi yang memudahkan individu yang bersangkutan untuk dapat melakukan manajemen dirí. Dengan kemampuan mana jemen diri yang tinggi, individu tidak sekedar mampu membuat tujuan untuk setiap aktivitas yang dilakukannya. namun juga mampu melakukan langkah-langkah efektif untuk mencapai tujuan tersebut, seperti: membuat skaia prioritas, mengorganisasikan diri dan lingkungan yang mendukung. Dengan kemampuan manajemen diri yang tinggi individu diharapkan dapat merencanakan masa depannya dengan baik, dan untuk mahasiswa pelaku organisasi, masa depan berarti juga dicapainya keseimbangan antara dunia akademis dan dunia organisasi 
yang dijalaninya. Dengan kata lain dapat disimpulkan juga bahwa aktif berorganisasi dapat memberikan kontribusi positif bagi mahasiswa tanpa mengganggu studi mereka sejauh mereka mampu melakukan manajemen terhadap dirinya sendiri.

\section{PENUTUP}

\section{Simpulan}

Berdasar hasil analisis dapat disimpulkan bahwa semakin tinggi kesesuaian antara konsep diri nyata dan ideal yang dimiliki mahasiswa pelaku organisasi (dalam hal ini Senat Mahasiswa dan Badan Eksekutif Mahasiswa tingkat fakultas), semakin tinggi pula kemampuan manajemen diri yang dapat ditakukannya, begitupun sebaliknya. Kesesuaian antara konsep diri nyata dan ideal dapat menjadi prediktor yang cukup kuat bagi kemarfipuan manajemen diri.

Selain itu, pengembangan Q-Sort sebagai salah sau metode pengukuran yang telah dilakukan dapat digunakan oleh peneitit tain.

\section{Saran}

Bagi peneliti selanjutnya dapat mengembangkan penelitian ini, baik dari segi tema maupun metode Q-Sort yang telah dilakukan, dengan memberlakukan pada jenis subjek selain mahasiswa pelaku organisasi yang ada di Senat Mahasiswa Fakultas dan Badan Eksekutif Mahasiswa Fakultas UGM, dan dapat memperłuas jumlah subjek penelitian.

Mahasiswa umumnya dan mahasiswa pelaku organisasi khususnya, perlu untuk menumbuhkan kesadaran untuk lebih mengenali potensi diri yang dimilikinya. Hal ini sanga: beralasan karena usaha tersebut dapat berperan besar dalam usaha mereka melakukan manajemen diri.

\section{DAFTAR PUSTAKA}

Burns, A. B. 1979. The Self Concept, in Theory, Measurement, Development, and Behavior. London: Longman Inc.

Covey, S. R.1994. TujuhKebiasaanMausia Yang Sangat Eloktif (terjemahan). Jakarta: Binarupa Aksara,

1996. First Things First, Dahulukan Yang Utama (ter iemahan). Jakarta: PT Gramedia Pustaka Utama.

Calhoun, J.F. \& Acocella, J.R. 1995.P sikologi Tentang Penyesuaian dan Hubungan Kemanusiaan (ter,iemahan). Semarang: IKIP Semarang Press.

Douglas, M. E.\& Dougias, D. N t980 Manage Your Time, Manage Your Work. Manage You Self. New York: Amacom.

Gie, T. L. 1996. Strategi Hidup Sukses. Yogyakarta: Penerbit Liberti.

Grinder, R. E 1978.Adolencense. 2nd Ed. New York: John Wiley and Sons.

Hall, C. S. \& Lindzey, G. 1959.Theoriesof Personality. New York : John Wiley and Sons, Inc.

Hurlock, E. B. 1980.Developmental Psychology: A Lile Span Approach. 5th Ed. New Delhi: Tata McGraw-Hill Publishing Company Ltd.

Lakein, A. 1997. Langkah-LangkahKeberhasilan Menguasai Waktu dan Hidup (terjemahan oleh Harahap A. dan Tahapary). Cetakan ketıga. Jakarta: Pustaka Tangga.

Macen, T. H. 1994. Time Management: Test of a Process Model. Journal of Applied Psychology, 3, 381-391. 
Manz, C.C. 1986. Seni Memimpin Diri Sendiri. Yogyakarta: Penerbit Kanisius.

Middlebrook, P. N. 1974.Social Psychology and Modem Lile. New York: McGraw Hill Publisher, Inc.

Partosuwido, S. R. 1992. Penyesuaian Diri Mahasiswa Dalam Kaitannya Dengan

- Konsep Diri, Pusat Kendali, dan Status Perguruan Tinggi. Disertasi (tidak diterbitkan). Yogyakarta: Fakultas Psikologi UGM.

Pedler, M. \& Boydell, T. 1985. Managing Yourself. London: Harper Collins Publishers.

Prawitasari. J.E. 1993. Kepemimpinan di Masyarakat. Handout Kuliah $\$ 2$ Psikologi UGM (tidak diterbitkan). Yogyakarta.

Rakhmat, J. 1985. Psikologi Komunikasi. Bandung: Penerbit Rosdakarya C.V.

Robinson, J.P. \& Shaver, P.R. 1973 Measures of Social Psychological Attitudes. Michigan: The institues for Social Research, The University of Michigan.

Rogers, C. R. \& Dymond, R. F. 1956.Psychotherapy and Personality Change. Chicago : University of Chicago Press.
Rogers, C.R. 1961. OnBecomingaPerson. Boston: Houghton Mifflin Company.

Stephenson, W. 1953. TheStudyofBeharior: Q-Technique and ins Methodology. London: Chicago Press.

Sulistyani, B. 1990. Hubungan Antara Konsep Diri dengan Perilaku Nakal di Kalangan Siswa-Siswa STM Negeri 1 Kodya Yogyakarta. Intisari Skripsi (tidak diterbitkan). Yogyakarta: Fakultas Psikologi UGM.

Utami, W. 1998. Perbedaan Tingkat Kecemasan antara Aktivis SM dan BEM Dengan Tingkat Kecemasan Non Aktivis di Lingkungan Fakultas Kedokteran UGM. Karya Tulis IImiah (tidak diterbitkan). Yogyakarta: Fakultas Kedokteran UGM.

Wicaksana, I. 1998. Demo, $\boldsymbol{P}$ Tinggi dan Kematangan Emosional. Dalam Kedaulatan Rakya: 29 Aprit 1998. Yogyakarta.

Wijayanti, A. W. 1992. Hubungan Kesenjangan Diri ideal-Diri Nyata Dalam Kerja Dengan Motivasi Kerja Pada Tenaga Kerja Wanita Matahari Departemen Store Yogyakarta. Skripsi (lidak diterbitkan). Yogyakarta: Fakultas Psikologi UGM. 